\title{
EFFECTS OF CADMIUM ON ULTRASTRUCTURE AND STEROIDOGENESIS IN CULTURED PORCINE OVARIAN GRANULOSA CELLS
}

\author{
P. MASSÁNYI, V. UHRÍN ${ }^{1}$, A. V. SIROTKIN ${ }^{2}$, K. PAKSY $^{3}$, ZS. FORGÁCS $^{3}$ \\ R. TOMAN, J. KOVÁČIK
}

Slovak University of Agriculture, Nitra, ${ }^{1}$ University of Constantin Philosopher, ${ }^{2}$ Research Institute of Animal Production, Nitra, Slovak Republic and ${ }^{3}$ National Institute of Chemical Safety, Budapest, Hungary

\author{
Received February 2, 2000 \\ Accepted May 31, 2000
}

\section{Abstract}

Massányi P., V. Uhrín, A. V. Sirotkin, K. Paksy, Zs. Forgács, R. Toman, J. Kováčik: Effects of Cadmium on Ultrastructure and Steroidogenesis in Cultured Porcine Ovarian Granulosa Cells. Acta Vet. Brno 2000, 69: 101-106.

Cadmium is an environmental risk factor having various toxic effects both in animals and in humans. The aim of this study was to study its effects on the structure and function of porcine ovarian granulosa cells cultured in vitro.

Ultrastructure of granulosa cells was studied after $48 \mathrm{~h}$ of culture with $(0.2,10$ and $20 \mathrm{ng}$ $\mathrm{CdCl}_{2} / \mathrm{ml}$ ) of without cadmium using transmission electron microscopy (TEM). Quantification of progesterone and $17-\beta$-oestradiol was performed directly from aliquots of the media from control and treated cells by radioimmunoassay (RIA).

After cadmium administration cell membranes were disintegrated. It was manifested by occurrence of vacuoles in the cytoplasm. The vacuoles contained fibrillar or membranous material. The Golgi complex rarely remained intact. Increased number of lysosomes was detected. With increasing cadmium concentrations the number of lipid droplets increased. In some cells the changes were less evident and dense mitochondria with distinct membranes were found. In other cell types the amount of mitochondrial matrix increased and that of membranes decreased. Some mitochondria fused with lysosomes. The endoplasmic reticulum rarely remained intact, and its dilation was well visible on transverse sections. Nuclei with distinct heterochromatin at the nuclear membrane were often observed. In these nuclei perinuclear cistern was dilated. Less frequently nuclei with condensed chromatin reminiscent of pyknosis were observed. Some nuclei had dispersed fine granular chromatin. In other cells changes were less evident, and comprised condensed chromatin in the central part of nuclei. These structural changes of granulosa cells exposed to cadmium were related to premature luteinization of these cells. In the evaluation of steroidogenesis we found that cadmium induced an increase in progesterone production, and a decrease in $17-\beta$-oestradiol production by ovarian granulosa cells; however, these differences were not significant. The results of our study elucidate some of the effects of cadmium on gonadal function, and should also serve to increase the level of awareness of its effects on human and animal health.

Cadmium, granulosa cells, ultrastructure, progesterone, 17- $\beta$-oestradiol

Cadmium is an environmental contaminant unique among metals because of its diverse toxic effects, extremely protracted biological half-life, low rate of excretion from the body, and predominant storage in soft tissues (primarily liver and kidney). However, cadmium also affects reproductive organs. Its action may be either direct, affecting the gonads and accessory organs, or indirect via interference with the hypothalamus - pituitary - gonadal axis (Paksy et al. 1992; Massányi and Uhrín 1996).

Background ovarian cadmium levels in control rats have been shown to be $0.01-0.03$ $\mathrm{mg} / \mathrm{kg}$ wet organ weight (Paksy et al. 1990). Also our previous studies report similar concentrations in rabbits - $0.03 \mathrm{mg} / \mathrm{kg}$ (Massányi et al. 1997), sheep - 0.01 (To man and Massányi 1996) and cows - 0.01 - 0.02 (Massányi et al. 1995). In humans,

Address for correspondence:

Doc. MVDr. Peter Massányi, PhD.

Department of Physiology and Anatomy of Farm Animals

D. University of Agriculture
Phone: +42187601479

F-mail: massanyi@afnet.uniag.sk

http://www.vfu.cz/acta-vet/actavet.htm 
concentrations of $0.1-0.65$ have been reported (Nriagu 1981). In the human ovary cadmium levels increase linearly between 30 and 65 years of age, from 0.03 to $1.3 \mathrm{mg} / \mathrm{kg}$ wet weight (V arga et al. 1993). A significant (6.73-7.93 $\mu \mathrm{g} / \mathrm{ml})$ amount of cadmium was measured in human ovarian follicular fluid (Zenzes et al. 1995).

Basic histological studies in rabbits showed that in the ovary cadmium causes a decrease in the number of primary follicles after i.p. administration $(1.5 \mathrm{mg} / \mathrm{kg})$. The number of atretic follicles was significantly $(P<0.05)$ higher after administration of cadmium. The percentage of growing follicles was significantly higher and that of stroma significantly lower in the control group in comparison with all experimental groups receiving i.p. or p.o. administration of cadmium (Massányi 1996; Massányi and Uhrín 1996). Cadmium chloride administered s.c. induced profound cellular and vascular changes in the ovary of prepubertal rats. The large and medium-sized follicles underwent immediate mass atresia and the smaller ones had the same fate after a brief period of resistance (Kar et al. 1959).

The aim of this study was to determine the ultrastructural alterations and steroidogenesis of porcine granulosa cell cultured with cadmium, an environmental risk factor known to inhibit ovulation.

\section{Materials and Methods}

Ovaries were obtained at local abattoir from pubertal Slovak white gilts at seven months of age, immediately prior to the onset of oestrous cyclicity (visual examination of ovarian state). One hour after the animals were killed the contents of all 1 - $4 \mathrm{~mm}$ follicles (Danko 1997) were aspirated using a $2 \mathrm{ml}$ syringe, and granulosa cells were separated from the follicular fluid by centrifugation for $5 \mathrm{~min}$ at $200 \mathrm{~g}$. After removal of the supernatant, granulosa cells were resuspended using a Pasteur pipette in sterile TCM - 199 (Sigma, St. Louis, MO, USA) supplemented with $5 \%$ bovine foetal serum (Veterinary Research Institute, Brno, Czech Republic). The sequence of centrifugation, medium replacement and pipetting was repeated three times. After the last centrifugation, granulosa cells were resuspended in the incubation medium TCM - 199 supplemented with $10 \%$ bovine foetal serum and $50 \mathrm{mg}$ antibiotic gentamicin/l (Pharmachim, Sophia, Bulgaria). Two millilitres of this suspension (concentration $1 \times 10^{6}$ cells $/ \mathrm{ml}$ determined by haemocytometer) were transferred to Petri dishes (Sterilin Ltd., Feltham, UK) and incubated at 37.5 ${ }^{\circ} \mathrm{C}$ in $5 \% \mathrm{CO}_{2}$ in humidified air for $48 \mathrm{~h}$. Cell viability (determined by Trypan blue stain) was $75-78 \%$. The medium was then replaced with new medium of the same composition containing, in addition, cadmium chloride (Sigma, St. Louis, MO, USA) at $0.2 \mathrm{ng} / \mathrm{ml}$ (group A), $10 \mathrm{ng} / \mathrm{ml}$ (group B) and $20 \mathrm{ng} / \mathrm{ml}$ (group C). Control medium (group K) contained no cadmium. Cadmium was dissolved in the culture medium immediately before use. After $48 \mathrm{~h}$ of culture with or without cadmium cells were separated, fixed in $2 \%$ paraformaldehyde and $2.5 \%$ glutaraldehyde in $0.2 \mathrm{M}$ phosphate buffer at $4{ }^{\circ} \mathrm{C}$ for $2 \mathrm{~h}$, dehydrated in a graded series of ethanol solution, and embedded in epoxy resin Ultrathin sections were stained with uranyl acetate and lead citrate and observed using $100 \mathrm{CX}$-II JOEL. From each experiment 20 electron microscopy sections from three different replicates were examined.

Quantification of progesterone and 17- $\beta$-oestradiol were performed directly from aliquots of the media from control and treated cells by radioimmunoassay (RIA). Ten replicate treatments were prepared per experiment. Steroids were measured either in blank control (medium cultured without cells), in control (medium conditioned by cells cultured without cadmium) and in experimental groups (medium conditioned by cadmium-treated cells). By calculation of values of hormones produced by cells the values of endogenous hormones (blank control) were always substracted from values of total steroids measured in a cell-conditioned medium to exclude the influence of endogenous steroids on assessment of steroid secretion by cultured cells.

The minimum detectable limit for progesterone was $0.5 \pm 0.02 \mathrm{ng} / \mathrm{ml}$ and the intra- and inter-assay variations were $5.6 \%$ and $7.9 \%$ respectively. Isotope (1,2,6,7-3H)-progesterone (code TRK 417, Amersham, Buckinghamshire, UK) with specific activity of $3.26 \mathrm{TBq} / \mathrm{mmol}$ and progesterone antibody (Code P-001, Steranti, UK) was used. Intra- and inter- variations of $17-\beta$-oestradiol were $6.3 \%$ and $9.2 \%$ respectively. Isotope $(2,3,6$, 7-3H)-oestradiol (code TRK 322, Amersham, Buckinghamshire, UK) was used. The 17- $\beta$-oestradiol standard and antiserum were kindly donated by Dr. Tibor Fehér (Semmelweis Medical School, First Department of Internal Medicine, Budapest, Hungary).

Analysis of variance and Scheffe's test were used to calculate basic statistic characteristics (mean, standard deviation) and to determinate significant differences in hormone production. Results of the RIAs were calculated after logarithmic transformation.

\section{Results}

In control culture, without cadmium administration, the cells had cytoplasmatic membranous structures free of pathological changes but in some cells vacuoles of various 
size bordered with membrane appeared (empty or filled with fibrillar material). Lysosomes containing fibrillar material or dense granules were also present. Cells as well as their nuclei had normal structure. Low numbers of lipid droplets in cytoplasm were observed.

In culture with serum $+0.2 \mathrm{ng} \mathrm{CdCl} / \mathrm{ml}$, cells with higher numbers of vacuoles, or lipid droplets were present (Plate I, Fig. 1). High amounts of vacuolized structures covered by simple membrane, or dilated endoplasmic membranes with peripheral dense granules were observed. In some vacuoles lipid droplets were present. Dilated mitochondria with less distinct structure appeared. Some membranes were similar in appearance to transverse or longitudinal sections of granular endoplasmic reticulum (GER). The structure of the chromatin was altered into condensed material or a powdered amorphous mass.

Granulosa cells in culture group with serum $+10 \mathrm{ng} \mathrm{CdCl} / \mathrm{ml}$ were damaged as in the previous group. Membranes of the Golgi complex were weakly developed. Vacuolisation of cytoplasm was present, and the vacuoles had sharp single membrane and contained fine fibrillar material, or they were filled with lipid droplets. Granulosa cells with dilated sacks of GER and condensed small mitochondria were observed. Nuclei were filled with homogenous dense chromatin. These nuclei had heterochromatin of low expression and invaginations. In some mitochondria distinct cristae remained (Plate I, Fig. 2). Dilated mitochondria were of low density, vacuoles contained fine dense material, and some of them contained lipid droplets (vacuoles and/or lysosomes had an appearance of autolysosomes).

Cells cultured with serum $+20 \mathrm{ng} \mathrm{CdCl} / \mathrm{ml}$ were similar in appearance to the previous group. In vacuoles concentrated membranous myelin formations were present. Vacuolisation of cytoplasm is reported (Plate II, Fig. 3), and lysosomes also occurred. The outer nuclear membrane was undulated and dilatation of perinuclear cistern occurred (Plate II, Fig. 4).

Hormone productions of granulosa cells without and with cadmium treatment are shown in Figs 5 and 6 . The highest production of progesterone was found in the group with addition of $10 \mathrm{ng} \mathrm{CdCl}_{2} / \mathrm{ml} \mathrm{(44.30 \pm 6.00}$ $\mathrm{ng} / \mathrm{ml}$ ), and when the dose of cadmium was increased to $20 \mathrm{ng} \mathrm{CdCl}_{2} / \mathrm{ml}$ its production decreased (34.94 \pm 6.51$)$. In the group with addition of $0.2 \mathrm{ng} \mathrm{CdCl} / \mathrm{ml}$ the progesterone level was $40.37 \pm 7.58 \mathrm{ng} / \mathrm{ml}$, and in the control group $29.31 \pm 13.50 \mathrm{ng} / \mathrm{ml}$.

Production of $17-\beta$-oestradiol by granulosa cells increased in group A (273.93 \pm 131.71$)$ more than in the other groups (control group $190.60 \pm 168.99$, group B $-236.87 \pm 120.04$, group $C-249.83 \pm 183.66)$. None of the differences were significant.

It can be concluded that addition of cadmium causes luteinisation of granulosa cells, as was demonstrated by the higher progesterone level in culture medium.

\section{Discusssion}

Problems in reproduction are well studied in relation to the development (Jančovičová et al. 1996), to the actual state of reproduction (Kolodzieyski et al. 1991; Kolodzieyski and Danko 1995;

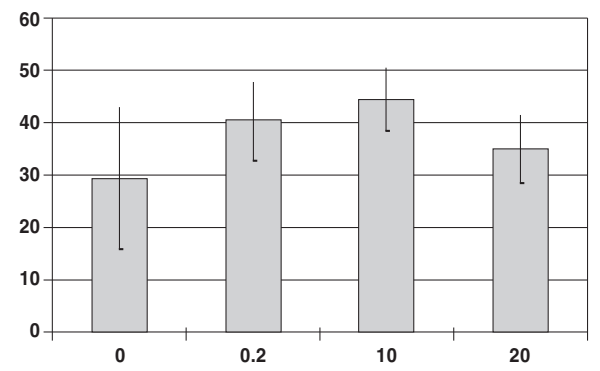

Fig 5. Effects of cadmium on progesterone concentration $(\mathrm{ng} / \mathrm{ml})$ of in vitro cultured porcine granulosa cells

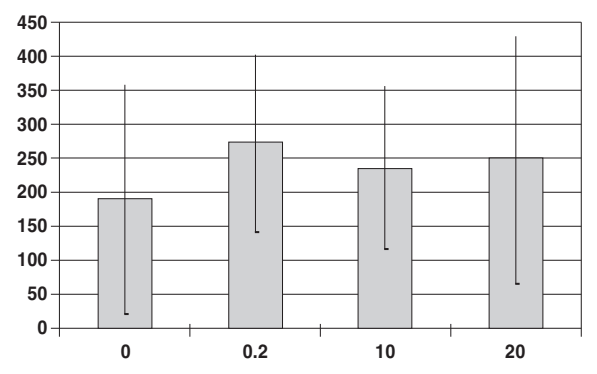

Fig. 6. Effects of cadmium on 17- $\beta$-oestradiol concentration $(\mathrm{pg} / \mathrm{ml})$ of in vitro cultured porcine granulosa cells 
Krajničáková et al. 1996) as well as to the environmental pollution (Varga et al. 1993; Legáth et al. 1996).

The toxic effects of cadmium on the reproductive organs of animals and humans are most completely described in testes (Webb 1972; Aoki and Hoffer 1978; Hew et al. 1993; Blottner et al. 1999). High cadmium accumulation is reported in the ovary of sheep (Bíre š et al. 1991). Cadmium levels in the ovary increase linearly between 30 and 60 years of age in women (Varga et al. 1993). Oedema of ovarian tissue, which is probably caused by vascular changes and also by low molecular weight of cadmium- and zinc-binding proteins present in the ovaries, which are not metallothionein is described. A correlation between metallothionein deficiency and high sensitivity to the effects of cadmium has been described (Waalkes et al. 1988). In another report, cadmium chloride treatment induced profound cellular and vascular changes in the ovary of prepubertal rats. The large and medium-size follicles underwent mass atresia. At $6 \mathrm{~h}$ after cadmium treatment there was vascular engorgement and haemorrhage in the theca (Paksy et al. 1992).

The major findings of this study have been that cadmium is able to induce alterations in the ultrastructure and function of cultured porcine granulosa cells in vitro. Cadmium influences the intracellular structure of granulosa cells with changes in membranous cellular structures. The structure of the nucleus was altered so that nuclei were changed into condensed material of dense chromatin. The most severe ultrastructure perturbations were induced by the lowest concentration of cadmium tested $(0.2 \mathrm{ng} / \mathrm{ml})$ but the higher cadmium levels also caused very evident changes, which were structurally similar. It seems that porcine granulosa cells are sensitive to a concentration $0.2 \mathrm{ng} \mathrm{CdCl}_{2} / \mathrm{ml}$ and that cellular alterations start at this level or below; we suggest that future studies should focus on lower concentrations to determine threshold levels. But the most general finding - the vacuolisation of cytoplasm was determined in all groups with addition of cadmium in comparison with control and seems to be a significant sign of cadmium toxicity. In addition to this structural effect, cadmium also altered progesterone and 17- $\beta$-oestradiol secretion, which are required for further stages of reproduction.

Exposure of human granulosa cells to cadmium resulted in morphological alterations in the monolayer depending on dose and exposure time (Paksy et al. 1997). At higher doses as well as low doses with longer exposure, cells began to separate from each other by contracting towards the centre and assuming a circular shape. In our experiments with $10 \mathrm{ng}$ $\mathrm{CdCl}_{2} / \mathrm{ml}$ and $20 \mathrm{ng} \mathrm{CdCl} / \mathrm{ml}$ treatment, the cytoplasm becames vacuolised and two types of lesions were present. Granulosa cells contained dilated sacks of granular endoplasmic reticulum and also vacuolar formations and dilated mitochondrias were described.

Increase of progesterone production by ovarian granulosa cells is reported. This conclusion is not in accordance with the findings declared by Paksy et al. $(1992,1997)$. These authors found a decrease of progesterone production by human granulosa cells after cadmium treatment in vitro. Cadmium did not cause a significant alteration in progesterone accumulation during $4 \mathrm{~h}$ incubation periods. Following $24 \mathrm{~h}$ cadmium decreased progesterone production (Paksy et al. 1992). We suggest that the degeneration and luteinisation of granulosa cells cause the progesterone production. Basal progesterone production of cadmium-treated cells remained unchanged $(20 \mathrm{ng} / \mathrm{ml})$ or was enhanced; this supports the theory of cadmium - calcium competition. Calcium has been reported not to influence basal pregnenolon production or estrogen synthesis from androgen substrates, or progesterone production from exogenously supplied sterol substrates in porcine granulosa cells whereas it is known that calcium ions influence the stimulatory action of LH and modulate the effects of cAMP on progesterone biosynthesis (Veldhuis et al. 1984).

A decrease in 17- $\beta$-oestradiol concentrations was observed; in this respect our results are similar to results obtained by Paksy et al. $(1992,1997)$ in human granulosa cells. 
These results contribute to our knowledge of the effects of cadmium on gonadal function, and should also serve to increase the level of awareness of its effects on human and animal health.

\section{Vplyv kadmia na ultraštruktúru a steroidogenézu kultivovaných ovariálnych granulóznych buniek ošípaných}

V práci sa sledoval vplyv kadmia ako rizikového faktora prostredia na ultraštruktúru a steroidogenézu kultivovaných granulóznych buniek vaječníka ošípaných. Zistili sme dezintegráciu membrán buniek po podaní kadmia. Dezintegrácia sa prejavovala výskytom vakuol v cytoplazme buniek, ktoré obsahovali fibrilárny alebo membranózny materiál. Golgiho komplex sa vyskytoval len ojedinele. Zistilo sa zvýšenie počtu lyzozómov. So zvyšujúcou sa koncentráciou kadmia sa zvyšoval aj počet tukových kvapôčok. V niektorých bunkách boli zmeny menej výrazné, s výskytom denzných mitochondrií so zretelnými membránami. V iných bunkách sme sledovali zvyšovanie sa zastúpenia matrix a úbytok membrán mitochondrií. U niektorých mitochondrií došlo k fúzii s lyzozómami. Častým nálezom bola dilatácia endoplazmatického retikula. Sledovali sme jadrá so zretelným heterochromatínom $\mathrm{v}$ blízkosti jadrovej membrány. U týchto buniek sme zistovali dilatáciu perinukleárnej cisterny. Menej často sme pozorovali bunky s kondenzovaným chromatínom, podliehajúcim pyknóze. Niektoré jadrá mali rozptýlený jemný granulárny chromatín. Tieto štrukturálne zmeny granulóznych buniek po ich kultivácii s kadmiom sú spôsobené luteinizáciou granulóznych buniek, nakolko tieto bunky sa predčasne dostávajú do luteálnej fázy. Tieto údaje potvrdzuje aj analýza steroidogenézy, kde sme zistili, že kadmium spôsobuje zvýšenie produkcie progesterónu a na druhej strane produkcia 17- $\beta$-estradiolu je znížená. Rozdiely však neboli štatisticky významné.

\section{Acknowledgements}

We thank Mrs. Alžbeta Sobčáková for her skilful technical assistance. This work was supported by the Ministry of Education of the Slovak Republic, VEGA Agency, Grants No. 1/3105/96 and 1/6127/99. We specially thank Greg Anderson, PhD. at Department of Physiology, Health Sciences Center, WVU, Morgantown for the English language revision.

\section{References}

AOKI, A., HOFFER, A. P. 1978: Reexamination of the lesions in rat testis caused by cadmium. Biol. Reprod. 18: $579-591$

BÍREŠ, J., VRZGULA, L., JUHÁSOVÁ, Z. 1991: Distribúcia rizikových prvkov v organizme oviec po príjme priemyselnej emisie v experimente. Vet. Med. (Praha) 36: 361-371

BLOTTNER, S., FRÖLICH, K., ROELANTS, H., STREICH, J., TATARUCH, F. 1999: Influence of environmental cadmium on testicular proliferation in roe deer. Reprod. Toxicol. 13: 261-267

DANKO, J. 1997: Ovarian mass, size and number of follicles in postparturient ewes. Acta Vet. Brno 66: 71-74

HEW, K. W., ERICSON, W. A., WELSH, M. J. 1993: A single low cadmium dose causes failure of spermation in the rat. Toxicol. Appl. Pharmacol. 121: 15-21

JANČOVIČOVÁ, J., DANKO, J., JANTOŠOVIČ, J. 1996: A histological study of the follicular development in the prenatal ovary of the sheep. Folia veterinaria 40: 15-20

KAR, A. B., DAS, R. P., KARKUN, J. N. 1959: Ovarian changes in prepubertal rats after treatment with cadmium chloride. Acta Biol. Med. Germ. 3: 372-399

KOLODZIEYSKI, L., DANKO, J., RAJTOVÁ, V. 1991: Porovnanie histochemickej aktivity niektorých enzýmov normálne vyvinutého vaječníka a vaječníka hermafrodita u kozy. Plzeň. lék. Sborn., Suppl. 63: 291-293

KOLODZIEYSKI, L., DANKO, J. 1995: A histological, histochemical, and immunohistochemical picture of the ovary of a hermaphrodite goat. Folia veterinaria 39: 107-110

KRAJNIČÁKOVÁ, M., BEKEOVÁ, E., LENHARDT, L., CIGÁNKOVÁ, V., VALOCKY, I., MARAČEK, I. 1999: Microscopic analysis of the uterine endometrium in postparturient ewes. Acta Vet. Brno 68: 9-12

LEGÁT, J., MLYNARČÍKOVÁ, H., ŠVICKÝ, E., LENHARDT, L., KAČMÁR, P., BEŇOVÁ, K., KOVÁČ, G. 1996: Acute oral toxicity of the herbicide Burex Eko in pheasant. Vet. Med. - Czech 41: 367-371 
MASSÁNYI, P., TOMAN, R., NAJMIK, F. 1995: Concentrations of cadmium in ovary, oviductus, uterus, testis and tunica albuginea of testis in cattle. J. Environ. Sci. Health, A30: 1685-1692

MASSÁNYI, P., UHRÍN, V. 1996: Histological changes in the ovaries of rabbits after an administration of cadmium. Reprod. Dom. Anim. 31: 629 - 632

MASSÁNYI, P. 1996: Štrukturálne zmeny vaječníka, vajcovodu a maternice samice králika po podaní kadmia. Monografia, VŠP Nitra: 1-70

MASSÁNYI, P., UHRÍN, V., VALENT, M. 1997: Correlation relationship between cadmium accumulation and histological structures of ovary and uterus in rabbits. J. Environ. Sci. Health A32: 1621-1635

NRIAGU J.O. 1981: Cadmium in the environment, Part II, Health effects, NY - Chichester -Brisbane - Toronto Singapore, John Wiley \& Sons, 1981: 35-70

PAKSY, K., NÁRAY, M., VARGA, B., KISS, I., FOLLY, G., UNGVÁRY, G. 1990: Uptake and distribution of $\mathrm{Cd}$ in the ovaries, adrenals, and pituitary in pseudopregnant rats: Effects of $\mathrm{Cd}$ on progesterone serum levels. Environ. Res. 51: 83-90

PAKSY, K., VARGA, B., LÁZÁR, P. 1992: Cadmium interferes with steroid biosynthesis in rat granulosa and luteal cells in vitro. BioMetals 5: 245-250

PAKSY, K., RAJCZY, K., FORGÁCS, ZS., LÁZÁR, P., BERNARD, A., GÁTI, I., KAÁLI, G.S. 1997: Effect of cadmium on morphology and steroidogenesis of cultured human ovarian granulosa cells. J. Appl. Toxicol. 17: 321-327

SOKOL, J., UHRÍN, V., MASSÁNYI, P., BREYL, I., KOŠUTZKÝ, J., UHRÍN, P. 1998: Kadmium a jeho výskyt v organizmoch živočíchov. Monografia, ŠVS SR Bratislava: 79-114

TOMAN, R., MASSÁNYI, P. 1996: Cadmium in selected organs of fallow-deer (Dama dama), sheep (Ovis aries), brown hare (Lepus europaeus) and rabbit (Oryctolagus cuniculus) in Slovakia. J. Environ. Sci. Health A31: 1043-1051

VARGA, B., ZSOLNAI, B., PAKSY, K., NÁRAY, M., UNGVÁRY, G. 1993: Age dependent accumulation of cadmium in the human ovary. Reprod. Toxicol. 7: 225-228

VELDHUIS, J. D., KLASE, P. A., DEMERS, L. M., CHAFOULEAS, J. G. 1984: Mechanism subserving calcium's modulation of luteinizing hormone action in isolated swine granulosa cells. Endocrinology 114: 441-449

WAALKES, M. P., REHM, S., PERANTONI, A. 1988: Metal binding proteins of the Syrian hamster ovaries apparent deficiency of metallothionein. Biol. Reprod. 39: 953-961

WEBB, M. 1972: Biochemical effects of $\mathrm{Cd}^{2+}{ }_{-}$-injury in the rat and mouse testis. J. Reprod. Fert. 30: 83-98

ZENZES, M. T., KRISHNAN, S., KRISHNAN, B., ZHANG, H., CASPER, R. F. 1995: Cadmium accumulation in follicular fluid in women in in vitro fertilization-embryo transfer is higher in smokers. Fertil. Steril. 64: 599-603 
Plate I

Massányi P. et al.: Effects of cadmium... pp. 101-106

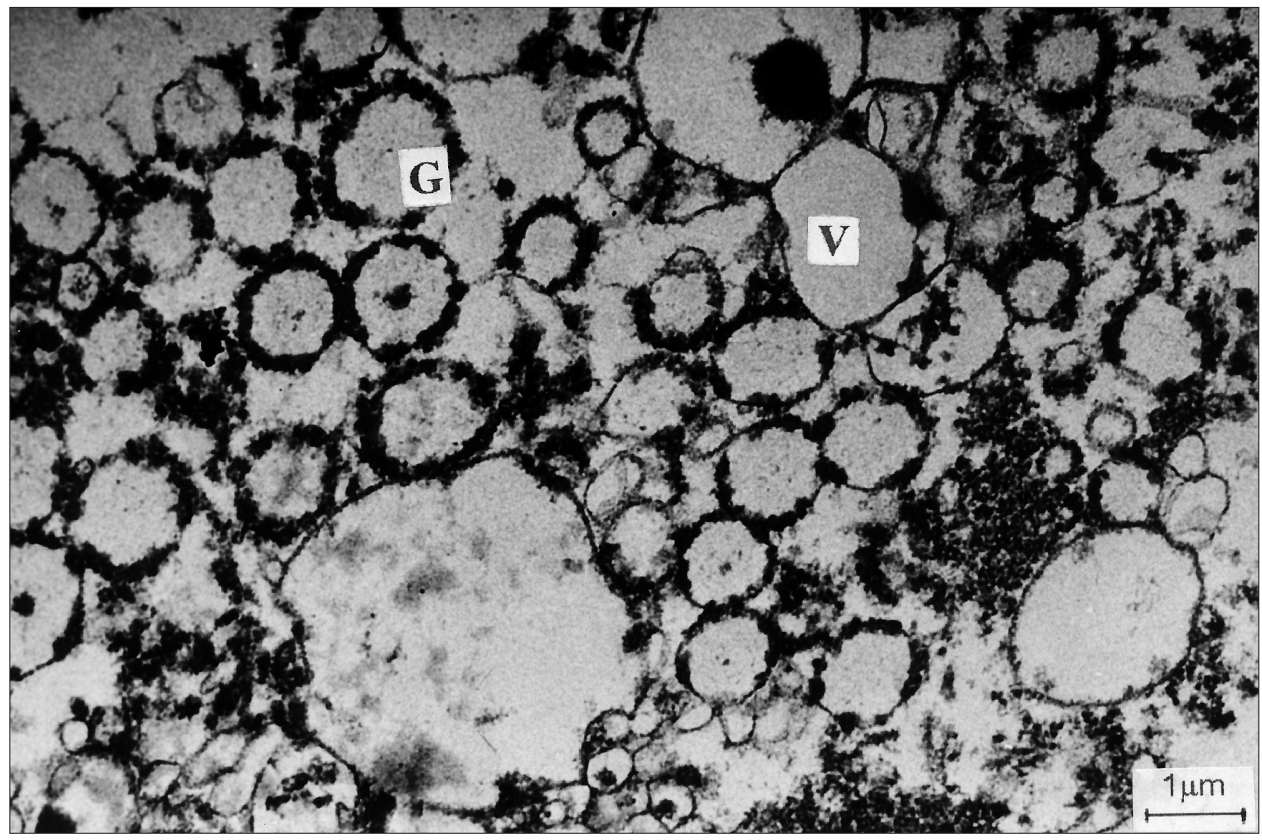

Fig. 1. Influence of cadmium on granulosa cells. After cell culture with cadmium $(0.2 \mathrm{ng} \mathrm{CdCl} 2 / \mathrm{ml})$ higher amount of vacuoles (V) in cytoplasma occurs. Cisternae of granular endoplasmic reticulum $(\mathrm{G})$ are dilated $(\times 10000)$.

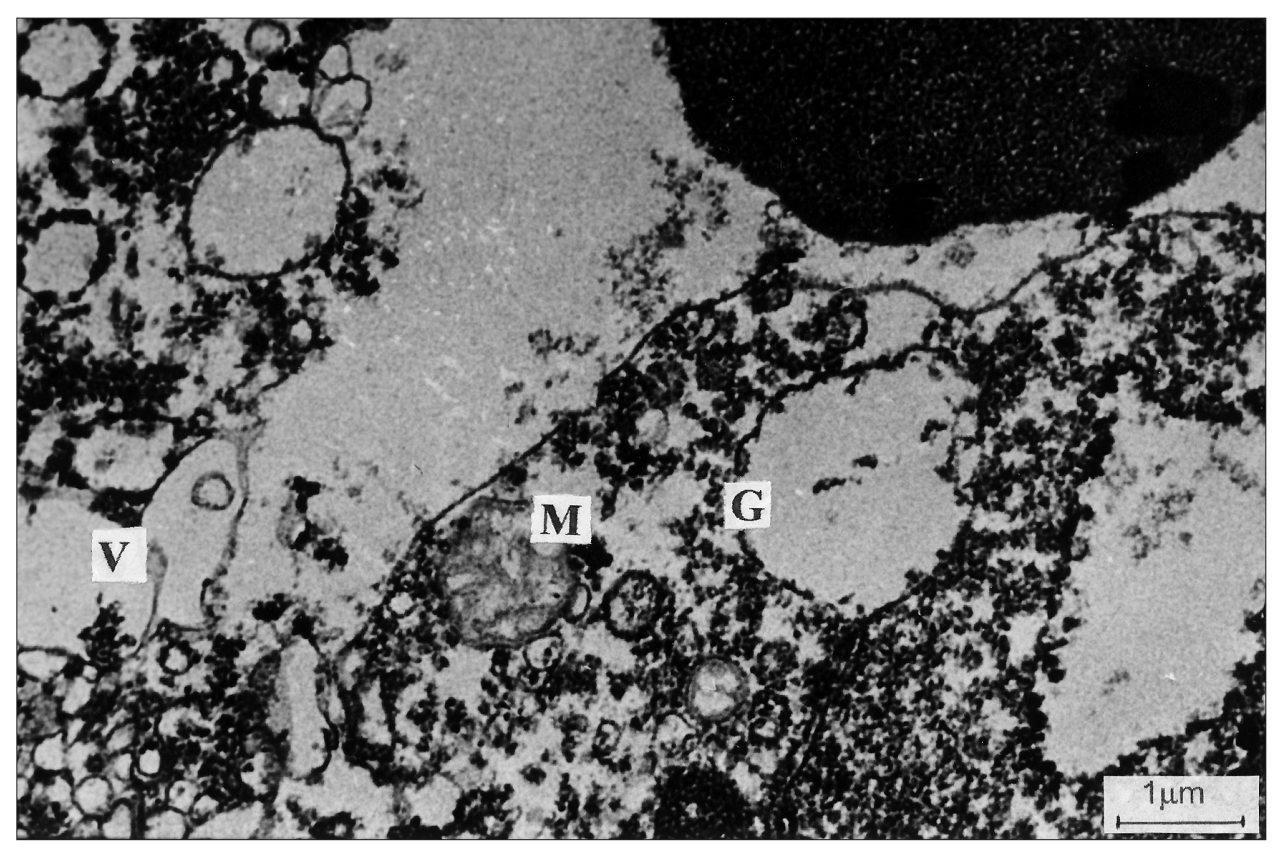

Fig. 2. Culture of granulosa cells with addition of cadmium $\left(10 \mathrm{ng} \mathrm{CdCl}_{2} / \mathrm{ml}\right)$ caused vacuolisation (V) of cytoplasm and dilation of granular endoplasmic reticulum $(\mathrm{G})$. In mitochondriae $(\mathrm{M})$ dilation and alterations in the inner mitochondrial membrane were found $(\times 7200)$. 


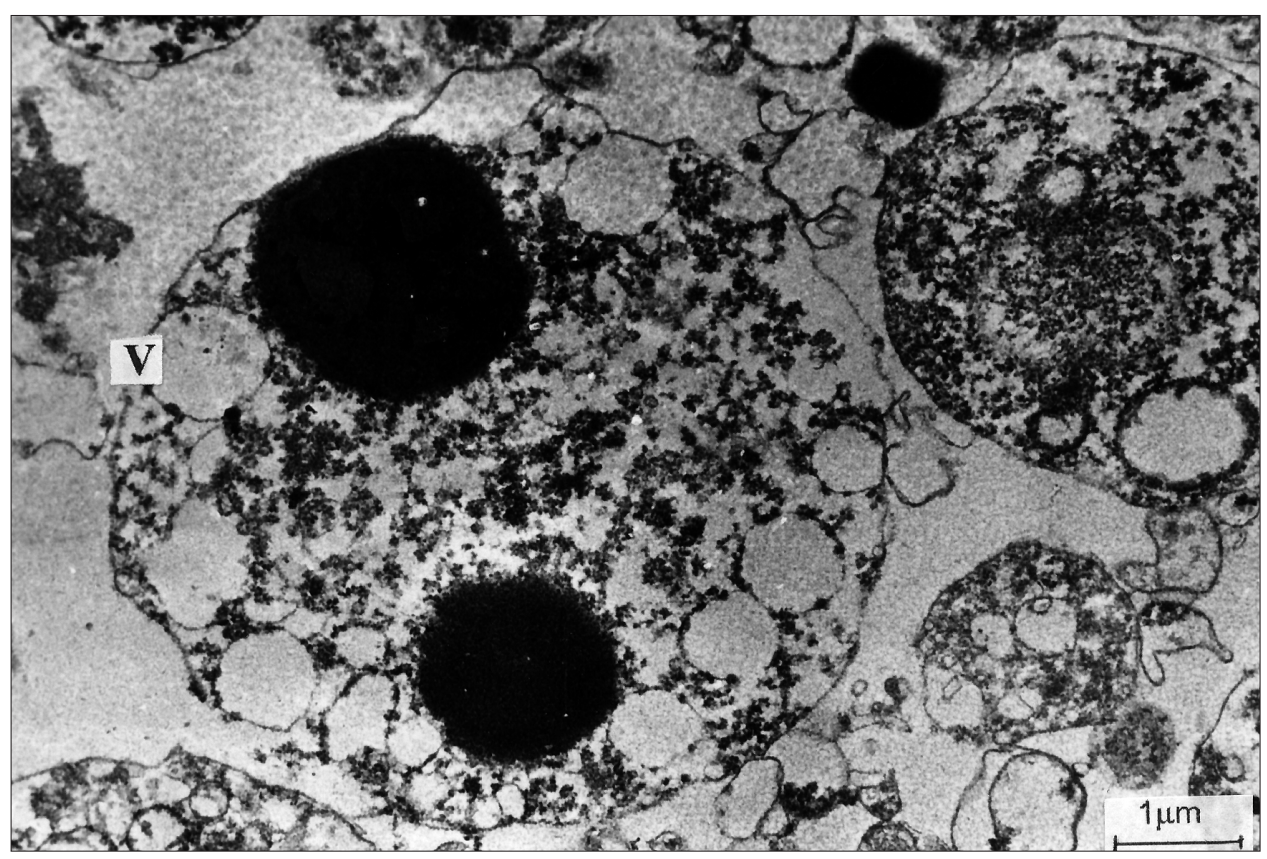

Fig. 3. After culture of granulosa cells with cadmium $(20 \mathrm{ng} \mathrm{CdCl} / \mathrm{ml})$ vacuolisation (V) of cytoplasm is seen $(\times 7200)$.

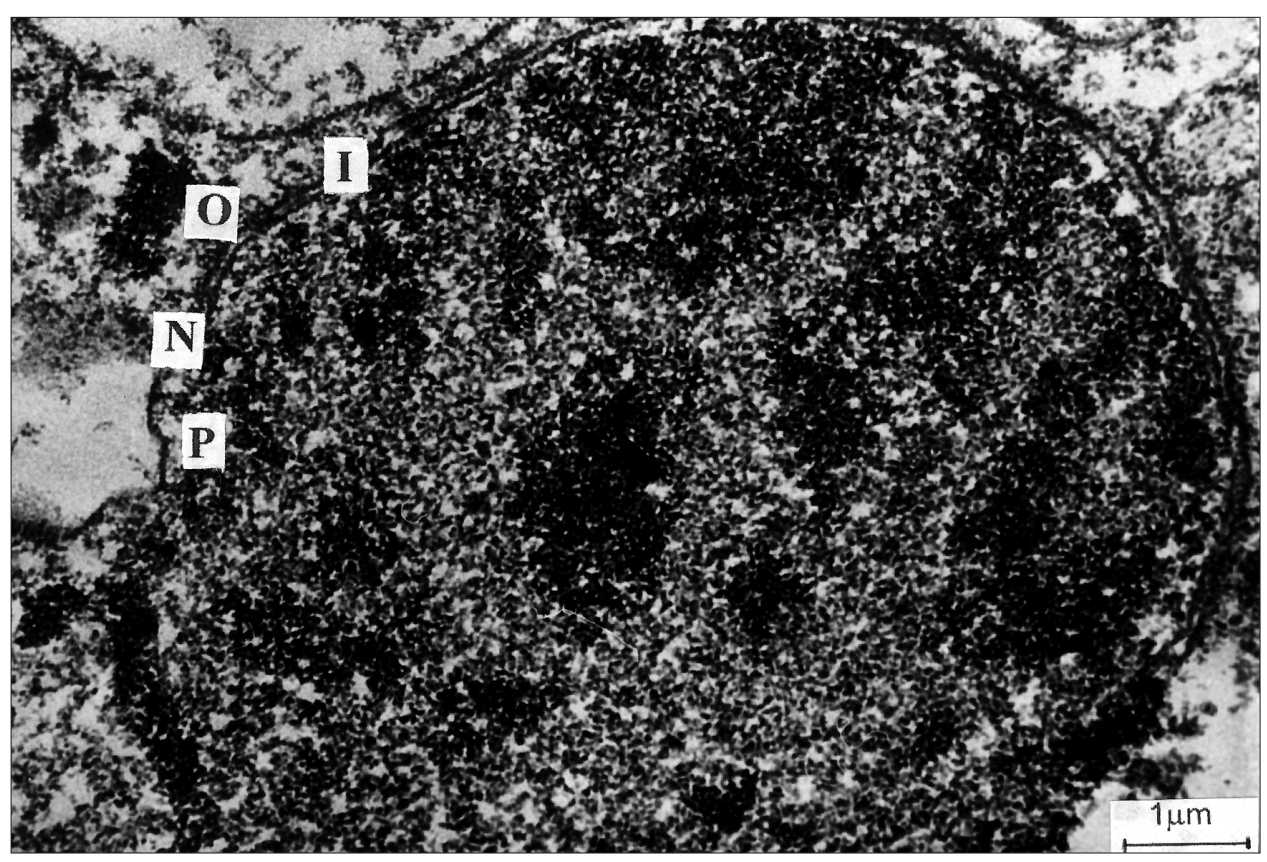

Fig. 4. Cadmium also affects the nucleus and cause undulation of nuclear membrane $(\mathrm{N})$. Perinuclear cisterna $(\mathrm{P})$ between inner $(\mathrm{I})$ and outer $(\mathrm{O})$ nuclear membrane is dilated $(\times 7200)$. 